УДК 338.24

JEL Classification: L21; M15; 013

DOI: https://doi.org/10.32317/2221-1055.202101084

Shichao CHANG, post-graduate student*

\title{
Analysis of the influence of factors of innovative activity of agro-industrial complex enterprises on the stability of their economic development
}

The purpose of the article is to develop a new methodological approach to the analysis of innovative activity of enterprises of the agro-industrial complex in order to ensure their sustainable economic development, taking into account the factors of economic growth.

Research methods. The scientific provisions on planning innovation activities and analysis of innovative processes (the essence and content of innovation activity of enterprises are justified), modeling and organization of innovation activity, forecasting its results in economic systems (modern trends in the development of methods for analyzing and assessing innovation activity of enterprises in the system activity), as well as general scientific methods of cognition: systemic (formulated the problems of assessing the innovative activity of enterprises from the standpoint of ensuring their sustainable development and determining potential ways to solve them), complex (analysis of the parameters of the innovative activity of domestic enterprises), abstract-logical (the influence of environmental factors on the innovative activity of the enterprise is analyzed), functional and structural-level research methods (the relationship of internal factors of the enterprise's innovative activity is considered), methods of analysis and synthesis (the relationship of the internal factors of the enterprise's innovative activity is analyzed), evolutionary and historical approaches (the relationship of the factors of the enterprise's innovative activity with the parameters of its sustainable development is considered).

Research results. The methodological foundations of the innovative activity of agro-industrial complex enterprises have been theoretically substantiated as the degree of intensity of their actions on the creation and development (practical implementation) of innovations in the context of rapidly changing external conditions and tough market competition. Despite the high cost of mistakes in the innovative development of agricultural enterprises, the analysis of the innovative activity of an enterprise is an important tool for ensuring their sustainable economic development.

Scientific novelty. The elements of scientific novelty lie in the theoretical substantiation and experimental confirmation of a new methodological approach to the analysis of the innovative activity of agricultural enterprises in order to ensure their sustainable economic development. This makes it possible to determine the tools for intensifying the activities of enterprises through building up and productive use of intellectual potential. The concept of "innovative activity of enterprises" is clarified and it is shown that this is one of the main characteristics of their innovative activity. The composition of the parameters of innovative activity of enterprises has been improved and a set of factors stimulating and restraining the innovative activity of agricultural enterprises has been determined. On the basis of the conducted analytical studies, the interrelation and power of the mutual influence of factors of innovative activity of enterprises, as well as the relationship of these factors with the parameters of sustainable economic development, were revealed.

Practical significance of the article lies in the possibility of using its provisions and conclusions when analysing the relationship of internal factors of innovative activity of an enterprise, as well as when analysing the relationship between factors of innovative activity of agricultural enterprises with an assessment of the sustainability of their market development. The proposed set of methodological recommendations makes it possible to assess the innovative activity of an enterprise in the interests of its sustainable economic development. Tabl.: 2. Refs.: 22.

Keywords: analysis; agro-industrial complex; economic; enterprises; development; innovative activity; sustainability; factors.

Chang Shichao - post-graduate student of the department of enterprise economics, Taras Shevchenko National University of Kyiv (60, Volodymyrska St., Kyiv, 01033)

E-mail: changshichao8888@126.com

ORCID iD https://orcid.org/0000-0003-2945-5220

Scientific problem. In the conditions of tough competition, the compliance of the internal

(C) Shichao Chang, 2021

Scientific supervisor - H. M. Filyuk, doctor of economic sciences, professor. environment of the enterprise with the growing market requirements is a key factor in successful activity and necessitates its constant transformation. Development and implementation of innovations is an effective way to increase the competitiveness of agricultural 
enterprises. The solution to the issue of increasing the competitiveness of Ukrainian agricultural producers cannot be achieved without developing the process of enhancing the innovative activity of agricultural enterprises. Now the level of innovative activity of Ukrainian enterprises is low due to the lack of an innovative culture and innovative mentality, the lack of a clear relationship between the main participants in the innovation process (developers and consumers of innovations), as well as information opacity and, as a result, low motivation to develop, promote, finance and purchase products innovation activities.

An expressive emphasis is needed on stimulating innovative activity, a radical rethinking of approaches to the development of innovative activity within the agribusiness enterprises themselves. It is advisable for subjects of innovation to create an effective innovation management system, to actively implement the results of R\&D, both their own and thirdparty organizations. It is necessary to find new sales markets and pay more attention to improving the level of personnel training. These measures are capable of ensuring the long-term progressive development of agricultural enterprises.

The complexity and multidimensionality of the problem of increasing innovative activity, as well as its significance in the process of increasing the efficiency of the agro-industrial complex enterprises, have determined the scientific and practical relevance of the topic of the article.

Analysis of recent research and publications. In the economic literature, the issues of management of innovative processes at an enterprise, sources and diffusion of innovations, innovation management are widely covered M. V. Alderete (2020); S. Brunswicker and W. Vanhaverbeke (2015); D. Chandrashekar, Bala M. H. Subrahmanya, K. Joshi, T. Priyadarshi, (2019); H. Chesbrough (2012) [1-4]. The problem of creating a system for assessing innovative activity at the micro level, determining quantitative indicators of the effectiveness of introducing innovations, while they are key factors in making managerial decisions, did not find adequate coverage. Few publications dealing with the assessment of the effectiveness of innovations at the micro level are devoted to the study of the topic «from the inside», that is, from the point of view of the enterprise, its management. Only some publications, as a research problem, indicate directions for increasing the innovative activity of enterprises to build up competitive advantages and accelerate the process of import substitution in the domestic market. Most of them are descriptive (M. Chouki, M. Talea, Ch. Okar, R. Chroqui, (2020); B. Ebersberger, C. Bloch, S. J. Herstad and E Van De Velde (2012); N. Furue, Y. Ab. Aziz, K. Mori, A. A. Hermawan, N. Assarut, W. Uehara, Y. Washida (2020); M. Grimaldi, L. Cricelli, M. Greco (2015)) [5-8].

Highly appreciating the contribution of these foreign scientists and their results, we formed the scientific basis of this article and put forward our proposals. It should be noted that the level of elaboration of the issues of enhancing the innovative activity of agricultural enterprises in relation to today's realities, in particular, the issue of increasing the innovative activity of agricultural enterprises by influencing their innovative potential of a group of factors that affect their innovative susceptibility, seems to us insufficient. The above makes it necessary to investigate this scientific problem at a new qualitative level and provide its systemic vision.

The purpose of the article is to develop a new methodological approach to the analysis of innovative activity of agricultural enterprises in order to ensure their sustainable economic development, taking into account the factors of economic growth.

Research methodology. The scientific provisions on planning innovative activities, analysing innovative processes, modelling and organizing innovative activities, predicting their results in economic systems, as well as general scientific methods of cognition: systemic, complex, abstract-logical, statistical, functional and structural research methods, methods of analysis and synthesis, evolutionary and historical approaches.

Research results. To develop effective mechanisms for stimulating innovation, let us turn to the content of the concept of «innovative activity». The analysis shows that the understanding of the term «innovative activity" in literary sources is ambiguous. Scientists M. Hossain and I. Kauranen (2016) innovative activity is revealed as a set of factors reflecting the intensity of innovative activity, which is based on the possibility of increasing the innovative potential of the enterprise [9]. Other researchers call innovative activity 
a generalized characteristic of the result of innovative activity. This characteristic reflects the susceptibility to the creation of innovations, which is manifested in the consumer properties of the product and in the ability to mobilize the innovative potential of the required quantity and quality. We are talking, among other things, about the hidden aspects of the innovation potential, which are able to ensure the validity of the methods used, as well as the rationality of the technology of the innovation process in terms of the composition and sequence of operations ( $C$. Lehrer, A. Wieneke, J. Brocke vom, R. Jung, S. Seidel, (2018) [10]. According to N. Nilsson and T. Minssen (2018) innovation activity is understood as the intensity of the implementation by economic entities of activities to develop and attract new technologies or improve products into economic circulation [11]. B. P. Platzek and L. Pretorius (2020) consider innovative activity as a certain set of technological, scientific, commercial, financial actions intended for innovations or acting as a basis for their creation [12]. Scientists Z. H. Zulkepli, N. Hasnan, S. Mohtar (2015) identify innovative activity with creative activity (energy), which arises in the production of goods and the end point of which is the addition of new scientific, technical, economic, organizational characteristics necessary for the consumer, as well as other indicators that are presented to the market [13]. From the point of view of $P$. Wynarczyk, $P$. Piperopoulos, M. McAdam (2013), the definition of "innovative activity" in its content is similar to the expression "activity of innovative activity", which indicates the level of use of innovative potential, which reveals the degree of successful implementation of an innovation, and also timely release from obsolete products [14]. L. Dahlander and D. M. Gann (2010) define the innovative activity of an enterprise as a complex characteristic of its intensity of innovative activity, based on the ability to mobilize innovative potential [15].

A broader definition was presented by D. Grimaldi (2020). According to this approach, the innovative activity of an enterprise is a complex characteristic of its innovative activity, including susceptibility to innovations, based on the competence in matters of progress in this type of activity, the degree of intensity of the actions taken to transform the innovation and their timeliness, the ability to mobilize the potential of the required quantity and quality, including its hidden sides, the ability to ensure the validity of the methods used, the rationality of the technology of the innovation process in terms of the composition and sequence of operations [16].

Considering the above, let us highlight the key details of innovation activity. Firstly, in the activities of agro-industrial, complex enterprises there must be a strategic component and the control center in the existing areas must relate to this moment in time, since the instability of the external environment has sharply increased recently.

The strategic base ensures high quality characteristics of innovation. Secondly, innovative activity should have a rational assessment of the actions taken from the perspective of their present, being responsible for the dynamics of the development of innovative activity in modern conditions and setting the pace of certain actions. If we exclude the moment of relevance in innovative activities, then the risk will increase that the products produced will become unnecessary in the market, and the resources spent on their production will not pay off in the future.

D. Chandrashekar, M. H. B. Subrahmanya, K. Joshi, T. Priyadarshi (2019) consider innovation activity as a set of enterprise actions to create innovations without taking into account the intensity of their implementation and the degree of novelty, help to raise the level of the enterprise in the market niche [3].

J. Grönlund, D. R. Sjödin, J. Frishammar (2010) consider innovation activity as the participation of manufacturers in the innovation process, that is, innovation, the transformation of ideas into new products [17].

From the point of view of B. H. Hall, F. Lotti, J. Mairesse, H. H. Francesca and L. Jacques (2015), innovative activity is a set of actions of an enterprise in the field of innovation, reflecting their intensity and timeliness, the ability to concentrate all the necessary potential, revealing the inner sides, justification of the chosen methods, technological level of the innovation process, a certain sequence of operations [18].

M. V. Alderete (2020) gives the following definition to innovation activity: the dynamics of innovation activity of an enterprise, which is determined by the speed and volume of use of innovation in the market [1]. 
According to J. Grönlund, D. R. Sjödin, J. Frishammar (2010), innovative activity characterizes the ability of an enterprise to perceive scientific and technical innovations in production, as well as the practical implementation of scientific and technical developments in the production of products [17].

E. Muralidharan and S. Pathak (2020) define innovation activity as part of management activities focused on innovative changes that determine the creation of innovative products using inventories, technologies, as well as the development of new sales markets [19].

A. Spithoven, B. Clarysse, M. Knockaert (2011) innovation activity is considered as a separate definition that determines the direction of innovation with the necessary content and procedure in accordance with a certain technology [20].

There are two conflicting points of view on the issue of classifying agricultural enterprises as innovatively active. According to the first point of view, an innovative-active enterprise is recognized as having little completed innovations over the past three years, that is, new or significantly improved products or services introduced on the market, or new or significantly improved production processes introduced into practice. According to the second point of view, agribusiness enterprises are considered to be innovatively active, which had expenses on innovations in the annual reporting period, regardless of their size, stage of the innovation process and the level of its completion.

Thus, the measurement of innovative activity is carried out at the enterprise level and is assessed by the following main characteristics: a) the presence of completed innovations; b) the degree of participation of the enterprise in the development of these innovations; c) the enterprise has special units that carry out research and development.

The multivariate interpretation of the economic content of the enterprise's innovative activity confirms the need for an unambiguous interpretation of this definition as a cumulative characteristic of innovative activity, which reflects the level of intensity of the actions performed, their compliance with a certain period of time, as well as the ability to accumulate all the necessary potential, substantiate and assess the effectiveness of the indicators used, the rationality of the selected technological methods of the innovation process in terms of the composition and sequence of operations A. Spithoven, B. Clarysse, M. Knockaert (2011) [20].

Innovative activity is influenced by many factors, which can be divided into global, caused by macroeconomic phenomena, as well as local, arising at the enterprise level. Global factors include political processes occurring within the country and in the world: the level of competitiveness in the sales market, relationships with government bodies, tax regulation (D. Grimaldi (2020)) [16].

Factors at the enterprise level include the level of production capacity, the availability of financial sources, qualified personnel, effective management, adaptation to the volatility of market conditions. However, the influence of these factors is not unambiguous, since for those enterprises of the agroindustrial complex in which there is significant wear and tear of equipment, these factors stimulate the use of innovations, and for other enterprises they can be a deterrent. At the same time, an increase in the role of managerial innovations is characteristic, but at the same time, the management of many enterprises does not correspond to current trends.

The relationship between global and local factors can be realized in the short and long term. This is due to the following: the impact of macroeconomic indicators in the short term (regulatory aspects, tax regulation, exchange rates) is large relative to the action of microeconomic objects. But the same factors in the long run lead to perturbations in the macroeconomic structure, which arise on the basis of the relationship existing in the enterprise between labor and capital, between owners, managers and hired personnel A. A. Fadelelmoula (2020) [21].

Thus, a decrease in state control over the institutional environment negatively affects the activities of agro-industrial enterprises that have obligations to buyers and suppliers, and the efficiency of using production potential also decreases. As a result, there is a drop in the level of innovation activity.

An institutional environment that does not correspond to the conditions of global competition creates an inconsistency of this environment with the position of the enterprise. This is reflected in the imperfection of management systems (including regulation of innovation) Fadelelmoula (2020) [21]. Ignoring the relationship between macro- and microeco- 
nomic factors in industrial policy is a good reason to stop the growth of innovation activity.
Depending on the degree of influence on innovative activity, the factors can be divided into motivating and inhibiting groups (Table 1).

Table 1

Factors of influence on the innovative activity of agricultural enterprises

\begin{tabular}{|c|c|c|}
\hline $\begin{array}{l}\text { Group of } \\
\text { factors }\end{array}$ & A factor that inhibits innovation activity & $\begin{array}{l}\text { Factor that stimulates innovation } \\
\text { activity }\end{array}$ \\
\hline Economic & $\begin{array}{l}\text { High level of risk associated with innovation; } \\
\text { low payback of innovative projects; lack of } \\
\text { funds; unfavorable credit conditions }\end{array}$ & $\begin{array}{l}\text { Varying consumer demand; } \\
\text { tough competition; growth in } \\
\text { profitability; high enterprise value }\end{array}$ \\
\hline Technological & $\begin{array}{l}\text { Difficulties in the implementation of scientific } \\
\text { and technical achievements; lack of spare } \\
\text { capacity; dominance of the interests of current } \\
\text { production }\end{array}$ & $\begin{array}{l}\text { Scientific and technical inventions; } \\
\text { severe deterioration of equipment }\end{array}$ \\
\hline $\begin{array}{l}\text { Organizational } \\
\text { and } \\
\text { managerial }\end{array}$ & $\begin{array}{l}\text { Lack of reforms in the structure of the } \\
\text { enterprise; strong control over the company; } \\
\text { lack of original ideas among staff of all levels; } \\
\text { orientation to established markets; the } \\
\text { difficulty of coordinating the interests of } \\
\text { participants in innovation processes; low level } \\
\text { of staff training }\end{array}$ & $\begin{array}{l}\text { Transformation of the enterprise } \\
\text { structure due to changes; division } \\
\text { of control over the company into } \\
\text { separate branches; formation of } \\
\text { target working groups }\end{array}$ \\
\hline Legal & $\begin{array}{l}\text { Lack of regulatory frameworks and institutional } \\
\text { areas; closed ness in the field of obtaining } \\
\text { information; crime situation }\end{array}$ & $\begin{array}{l}\text { A documentary base that stimulates } \\
\text { the development of innovative } \\
\text { activities; governmental support }\end{array}$ \\
\hline Socio-cultural & $\begin{array}{l}\text { Reduction of the credit mechanism operating in } \\
\text { the enterprise; fear of uncertainty and change } \\
\text { of status; decline in effective demand }\end{array}$ & $\begin{array}{l}\text { Motivation of personnel } \\
\text { for innovative processes; } \\
\text { creating opportunities for } \\
\text { self-realization; the ability } \\
\text { to release creativity }\end{array}$ \\
\hline
\end{tabular}

Source: Improved for D. Grimaldi (2020) [16].

There are external and internal factors influencing innovation activity. External factors mean an unstable state of the external environment; this is a key reflection of the time factor, investment and innovation climate, innovative competitive environment. The key external factors of a positive impact on the innovative activity of agro-industrial complex enterprises are institutional changes in the scale of the economy, transformations at the enterprise level (changes in the form of ownership and regulation), aggravation of the competition among competitors in the market S. Sağ, B. Sezen, M. Güzel (2016) [22].

Internal factors of positive influence include the openness of the enterprise, the mobilization of the capacity of personnel and management, the strategic flexibility of the enterprise, as well as a commendable attitude towards innovations and the development of personnel in this direction. Physical deterioration of equipment, costs associated with energy sources, low throughput, insufficient personnel qualifications are considered internal factors of negative impact. The corresponding innovation climate gives positive dynamics in the implementation of innovations, increases the return on their commercialization. The personnel of the enterprise, associated with the changes, should at their level assess their adequacy, as well as the expected efficiency from their implementation D. Grimaldi (2020) [16].

Indeed, the more novelty the product is, the higher the risk of its use. If innovations introduced into production have a small degree of novelty, then the surrounding enterprises perceive such innovations indifferently, since there is a certain psychological threshold of perception, overcoming which one can count on the emergence of interest. If the product has a high degree of novelty, then the interest will be higher. It is possible to determine the level of positive perception of innovation by personnel by filling out questionnaires, psychological tests, and professional certification A. A. Fadelelmoula (2020) [21].

The correctly chosen form of incentive influences the results of the enterprise's innovative activity. There are three forms of stimulating the innovative activity of an enterprise: 
1) provision of state support for innovative activity;

2) organization of extra-budgetary funding;

3) motivation of participants in innovative activities.

The state can provide support for innovation activity of agricultural enterprises in direct and indirect forms. With direct government regulation, two methods are used: administrativedepartmental and program-targeted.

Under the administrative-departmental method, subsidized financing is used; creation of special organizations within the executive branch; facilitating the exchange of scientific and technical specialists between organizations such as universities, industrial enterprises and government laboratories; application of incentive measures to individuals and enterprises that make a significant contribution to the development of science and technology. As part of the implementation of the methods of the program-targeted form of state regulation of innovations, specific financing of the latter is made through state targeted programs to support innovations.
Indirect regulation creates favorable conditions for innovative activity. This could include the liberalization of tax and depreciation laws; development and implementation of legislative norms; creation of social infrastructures.

Since budgetary resources are limited, the main source of funding for the innovative activity of agro-industrial complex enterprises is extra-budgetary funds. Here, to stimulate innovation, the use of enterprises' own funds takes place; extra-budgetary funds; funds received in the financial market; funds received in the order of redistribution. Most of the enterprises finance investment activity on their own from the profit received from the sale of products, from financial transactions; depreciation charges; proceeds from the sale of retired property; stable liabilities; targeted receipts. Commercial loans also play an important role in financing innovation activities.

The relationship between external and internal factors in combination with objective and subjective factors is presented in table 2.

Table 2

The relationship of internal and external factors in combination with objective and subjective factors

\begin{tabular}{|c|l|l|}
\hline Factor & \multicolumn{1}{|c|}{ Internal factor } & \multicolumn{1}{c|}{ External factor } \\
\hline Objective & $\begin{array}{l}\text { The form of ownership, which determines } \\
\text { the nature of the interests of the } \\
\text { enterprise; the size of the enterprise; } \\
\text { industry affiliation; enterprise } \\
\text { specialization and others }\end{array}$ & $\begin{array}{l}\text { Natural and climatic, internal political } \\
\text { conditions, as well as the situation at the } \\
\text { international level; the level of scientific } \\
\text { and technological progress in the world } \\
\text { arena and others }\end{array}$ \\
\hline \multirow{5}{*}{ Subjective } & $\begin{array}{l}\text { Intellectual and creative potential of the } \\
\text { enterprise personnel; the use of new } \\
\text { technologies for managing business } \\
\text { structures; flexibility of the organizational } \\
\text { structure; enterprise investment policy }\end{array}$ & $\begin{array}{l}\text { Competitive enterprise strategies; cus- } \\
\text { tomer behavior, determines the need for } \\
\text { innovative products; communication with } \\
\text { authorities, customers, business partners, } \\
\text { investors, etc. }\end{array}$ \\
\hline
\end{tabular}

Source: Improved for A. A. Fadelelmoula (2020) [21].

Depending on their content and sphere of origin, the factors of innovative activity of the enterprise are divided into four groups: economic and technological; political and legal; socio-psychological and cultural; organizational and managerial. All of them can have both a stimulating and a hindering effect on the innovative activity of an enterprise $S$. Sağ, B. Sezen, M. Güzel (2016) [22].

Let's consider their features in more detail. Economic and technological factors are associated with the presence of a certain reserve of financial and material and technical means and progressive technologies necessary for the functioning of scientific, technical and economic infrastructure. All this contributes to the innovative activity of the enterprise. At the same time, the lack of financial resources to finance innovative projects, the lack of reserve capacities and the dominance of the interests of current production can slow down the innovative activity of agricultural enterprises.

The legislative framework for the implementation of the enterprise's innovative activities determines factors of a political and legal nature. Legislative measures and incentives that encourage innovators, state support for innovative activity can stimulate the development of innovative activities of agricultural enterprises. The presence of restrictions 
on the part of tax, antimonopoly, patent licensing and depreciation legislation, on the contrary, impede its development.

Socio-psychological and cultural factors of a stimulating nature are reduced to moral encouragement of participants in the innovation process. They find their reflection in public recognition, providing opportunities for selfrealization of participants in the innovation process, freeing up creative labor and creating a normal psychological climate in the work collective. Socio-psychological and cultural factors of a hindering nature are reflected in the resistance to change on the part of employees of the enterprise $A$. Spithoven, B. Clarysse, M. Knockaert (2011) [20].

Organizational and managerial factors activate and stimulate the innovative activity of the enterprise, provided the organizational structure is flexible, the democratic style of management, the prevalence of horizontal information flows. An important role here is played by planning and allowing adjustments, as well as autonomy, decentralization and the formation of targeted working groups. Organizational and managerial factors of a hindering nature lie in the established organizational structure of the enterprise, an excessive degree of centralization, an authoritarian management style, departmental isolation and the prevalence of vertical information flows. Among other things, this group of factors includes the orientation of the business towards short-term payback and established markets, a rigid planning system and the difficulty of reconciling the interests of participants in innovation processes (M. V. Alderete (2020) [1].

The factor that can activate innovative activity is international competition in the domestic market. In the conditions of the openness of the internal market, an enterprise in a separate country becomes an open system, which significantly changes the nature of competition in all market segments. It is rather difficult to carry out innovative activities focusing simultaneously on the "passive" internal market and the "active" external market. To develop innovative relationships, it is necessary to know the needs, incentives and requirements of the single market. The openness of the domestic market creates conditions for a chain reaction of the spread of innovations, their multiplication, elasticity of demand in terms of price and quality parameters. At the same time, innovation costs are viewed by enterprises as inevitable investments to ensure "survival" in a competitive environment.

An important factor in the development of innovative activity is the quality of the workforce. A higher quality of the labor force, characterized by a higher level of education and qualifications of workers, leads to a more efficient use of production resources. The educational level reflects the creative ability of the staff to perceive new ideas that have appeared on the market. The quality of the workforce determines the ability of agribusiness enterprises to carry out their own R\&D or copy new products from other enterprises (J. Grönlund, D. R. Sjödin, J. Frishammar) [17].

Enterprises that use the principles of a learning organization become an attractive place of work for highly skilled creative workers, and improve relationships with customers and partners. Science plays a special role in this. Therefore, it should be closely integrated into production, become a participant in the innovation cycle of development, dissemination and use of innovations (D. Chandrashekar, M. H. B. Subrahmanya, K. Joshi, T. Priyadarshi (2019) [3].

Competitive opportunities can be judged by the indicators of the relative market share controlled by the enterprise, the speed of reaction to changes in the market situation. Technical capabilities are due to the parameters of the equipment, the technological scheme of production. Of particular note is the potential of organizational culture in promoting innovation and the role of strong leadership in creating such a culture.

Conclusions. An important factor in the development of an enterprise's innovative activity is the quality of the workforce. A high quality workforce, characterized by a higher level of education and qualifications of workers, leads to a more efficient use of production resources. The educational level reflects the creative ability of the staff to perceive new ideas that have appeared on the market. The quality of the workforce determines the ability of agribusiness enterprises to carry out their own R\&D or copy new products from other enterprises.

To reduce the influence of negative factors on innovation activity, it is urgently required to create a system for monitoring the effectiveness of the use of innovative infrastructure facilities, implement pilot projects 
to process mechanisms for supporting largescale innovation programs of business structures, in particular, support for cluster initiatives, and widespread implementation of international standards.

The low innovation activity of small and medium-sized enterprises in the agroindustrial complex brings to the fore the measures to improve the incentive mechanism for workers, attracting highly qualified specialists to the agricultural sector, where the level of staff turnover is several times higher than the threshold value.

The foundations of organizational structures of innovative activity are revealed. In this regard, a system of classification of the factors of innovative activity is proposed and the selection among them of the most significant at the present stage of economic development, including institutional changes, the development of innovative infrastructure, state innovation policy, cyclical development of the economy and innovation, regionalization and socialization of state regulation, is substantiated. A system for assessing the nature, dynamics and main directions of innovative activity of agricultural enterprises has been developed.

The advantages of indirect methods of state regulation of innovations in modern

\section{References}

1. Alderete M. V. Towards Measuring the Economic Impact of Open Data by Innovating and Doing Business. International Journal of Innovation and Technology Management, World Scientific Publishing Co. Pte. Ltd. 2020. №. 17(03). P. 1-20. https://doi.org/10.1142/S0219877020500224.

2. Brunswicker S., Vanhaverbeke W. Open Innovation in Small and Medium-Sized Enterprises (SMEs): External Knowledge Sourcing Strategies and Internal Organizational Facilitators. Journal of Small Business Management. 2015. № 53(4). P. 12411263. https://doi.org/10.1111/jsbm. 12120.

3. Chandrashekar D., Subrahmanya M. H. B., Joshi K., Priyadarshi $T$. Effect of Innovation on Firm Performance - The Case of a Technology Intensive Manufacturing Cluster in India, International Journal of Innovation and Technology Management, World Scientific Publishing Co. Pte. Ltd. 2019. № 16(07). P. 1-31. https://doi.org/10.1142/S0219877019500524.

4. Chesbrough $H$. Open innovation: Where We've Been and where We're Going. Research-Technology Management. 2012. № 55(4). P. 20-27. https://doi.org/10.5437/08956308X5504085.

5. Chouki M. Talea M., Okar Ch., Chroqui R. Barriers to Information Technology Adoption Within Small and Medium Enterprises: A Systematic Literature Review, International Journal of Innovation and Technology Management, World Scientific Publishing Co. Pte. Ltd. 2020. № 17(01). P. 1-42. https://doi.org/10.1142/S0219877020500078.

6. Ebersberger B., Bloch C., Herstad S. J., Van De Velde E. Open Innovation Practices and their Effect on Innovation Performance. International Journal of Innovation and Technology Management. 2012. № 9(6). P. 1-22. https://doi.org/10.1142/ S021987701250040X. conditions in Ukraine are substantiated: indirect methods of state support ensure the autonomy of the agricultural sector and its economic responsibility for the choice of research and development areas and their implementation. Direct methods do not create an artificially supported market of knowledge and innovations, with the help of which a unified approach to stimulating innovations in the agro-industrial complex is provided.

To increase the efficiency of the innovative potential of the enterprise, special attention should be paid to:

1) monitoring the progress of new product development and its implementation;

2) consideration of projects for creating new products;

3) pursuing a unified innovation policy, coordinating activities in this area in production units;

4) providing finance and material resources for innovation programs;

5) providing enterprises with qualified personnel, creating temporary target groups for a comprehensive solution to innovative problems - from an idea to a batch production of products;

6) development of plans and programs of innovation.

\section{References}

1. Alderete, M.V. (2020). Towards Measuring the Economic Impact of Open Data by Innovating and Doing Business. International Journal of Innovation and Technology Management, Vol. 17, No 03., 2050022 [In English]. https://doi.org/10.1142/ S0219877020500224.

2. Brunswicker, S. \& Vanhaverbeke, W. (2014). Open Innovation in Small and Medium-Sized Enterprises (SMEs): External Knowledge Sourcing Strategies and Internal Organizational Facilitators. Journal of Small Business Management, Vol. 53, Issue 4, pp. 1241-1263 [In English]. https://doi.org/10.1111/jsbm.12120.

3. Chandrashekar, D., Subrahmanya, M.H.B., Joshi, K. \& Priyadarshi, T. (2019) Effect of Innovation on Firm Performance The Case of a Technology Intensive Manufacturing Cluster in India, International Journal of Innovation and Technology Management, Vol. 16, No 07, 1950052 [In English]. https://doi.org/10.1142/S0219877019500524.

4. Chesbrough, H. (2012). Open innovation: Where We've Been and where We're Going. Research-Technology Management, Vol. 55, Issue 4, pp. 20-27 [In English]. https: / /doi.org/10.5437/08956308X5504085.

5. Chouki, M., Talea, M., Okar, Ch. \& Chroqui, R. (2020). Barriers to Information Technology Adoption Within Small and Medium Enterprises: A Systematic Literature Review. International Journal of Innovation and Technology Management, Vol. 17, No. 01, 2050007 [In English]. https: / / doi.org/10.1142/S0219877020500078.

6. Ebersberger, B., Bloch, C., Herstad, S.J. \& Van De Velde, E. (2012). Open Innovation Practices and their Effect on Innovation Performance. International Journal of Innovation and Technology Management, Vol. 9, No. 06, 1250040 [In English]. https://doi.org/10.1142/S021987701250040X. 
7. Furue N., Aziz Y. Ab. Mori K., Hermawan A. A., Assarut N., Uehara W., Washida Y. Low-Risk Innovative Ideas with High Self-Confidence: Innovation Process Characteristics in ASEAN Countries, International Journal of Innovation and Technology Management, World Scientific Publishing Co. Pte. Ltd. 2020. № 17(02). P. 1-19. https://doi.org/10.1142/S0219877020500121.

8. Grimaldi M., Cricelli L., Greco M. Open Innovation Actions and Innovation Performance: A Literature Review of European Empirical Evidence. European Journal of Innovation Management. 2015. № 18(2). P. 150-171. https://doi.org/10.1108/ EJIM-07-2013-0074.

9. Hossain M., Kauranen I. Open innovation in SMEs: A Systematic Literature Review. Journal of Strategy and Management. 2016. № 9(1). P. 58-73. https://doi.org/10.1108/JSMA08-2014-0072.

10. Lehrer C., Wieneke A., vom Brocke J., Jung R., Seidel $S$. How Big data Analytics Enables Service Innovation: Materiality, Affordance, and the Individualization of Service. Journal of Management Information Systems. 2018. № 35(2). P. 424-460. https: / /doi.org/10.1080/07421222.2018.1451953.

11. Nilsson N., Minssen T. Unlocking the Full Potential of Open Innovation in the Life Sciences Through a Classification System. Drug Discovery Today. 2018. № 23(4). P. 771-775. https://doi.org/10.1016/j.drudis.2018.01.002.

12. Platzek B. P., Pretorius L. Regional Cooperation in a Thriving Entrepreneurial Economy: A Holistic View on Innovation, Entrepreneurship and Economic Development, International Journal of Innovation and Technology Management, World Scientific Publishing Co. Pte. Ltd. 2020. № 17(03). P. 124. https://doi.org/10.1142/S0219877020500145.

13. Zulkepli Z. H., Hasnan N., Mohtar S. Communication and Service Innovation in Small and Medium Enterprises (SMEs). Procedia - Social and Behavioral Sciences. 2015. № 211. P. 437-441. https://doi.org/10.1016/j.sbspro.2015.11.057.

14. Wynarczyk P., Piperopoulos P., McAdam M. Open Innovation in Small and Medium-Sized Enterprises: An Overview. International Small Business Journal. 2013. № 31(3). P. 240255. https: //doi.org/10.1177/0266242612472214.

15. Dahlander L., Gann D. M. How Open is Innovation. Research Policy. $2010 . \quad$ №. 39(6). P. 699709. https://doi.org/10.1016/j.respol.2010.01.013.

16. Grimaldi D. Factors Affecting Big Data Analytics Based Innovation Processes. A Spanish Evidence, International Journal of Innovation and Technology Management, World Scientific Publishing Co. Pte. Ltd. 2020. № 17(05). P. 1-21. https: / /doi.org/10.1142/S0219877020500364.

17. Grönlund J., Sjödin D. R., Frishammar J. Open Innovation and the Stage-Gate Process: A Revised Model for New Product Development. California Management Review. 2010. № 52(3). P. 106-131. https://doi.org/10.1525/cmr.2010.52.3.106.

18. Hall B. H., Lotti F., Mairesse J., Francesca H. H., Jacques L. In SMEs?: Empirical Evidence Innovation and Productivity for Italy, Small Business Economics. 2015. № 33(1). P. 1333. https://doi.org/https://doi.org/10.1007/sl.

19. Muralidharan E., Pathak S. Contextualizing Technology Adoption and Self-Expression for Technology Entrepreneurial Innovation, International Journal of Innovation and Technology Management, World Scientific Publishing Co. Pte. Ltd. 2020. № 17(04). P. 1-25. https://doi.org/10.1142/S0219877020500261.

20. Spithoven A., Clarysse B., Knockaert M. Building Absorptive Capacity to Organise Inbound Open Innovation in Traditional Industries. Technovation. 2011. № 31(1). P. 10-21. https://doi.org/10.1016/j.technovation.2010.10.003.

21. Fadelelmoula $A$. A. Factors Influencing the Realization of Competitive Advantage in the Private Portals Context, International Journal of Innovation and Technology Management, World Scientific Publishing Co. Pte. Ltd. 2020. №. 17(04). P. 130. https: / /doi.org/10.1142/S0219877020500285

22. Sağ S., Sezen B., Güzel M. Factors that Motivate or Prevent Adoption of Open Innovation by SMEs in Developing Countries and Policy Suggestions. Procedia - Social and Behavioral Sciences. 2016. № 235(24). P. 756-763. https://doi.org/10.1016/J.SBSPRO.2016.11.077.
7. Furue, N., Aziz, Y.Ab., Mori, K., Hermawan, A.A., Assarut, N., Uehara, W. \& Washida, Y. (2020). Low-Risk Innovative Ideas with High Self-Confidence: Innovation Process Characteristics in ASEAN Countries. International Journal of Innovation and Technology Management, Vol. 17, No. 02, 2050012 [In English]. https: //doi.org/10.1142/S0219877020500121.

8. Greco, M., Grimaldi, M. \& Cricelli, L., (2015). Open Innovation Actions and Innovation Performance: A Literature Review of European Empirical Evidence. European Journal of Innovation Management, Vol. 18, No. 2, pp. 150-171 [In English]. https: / /doi.org/10.1108/EJIM-07-2013-0074.

9. Hossain, M. \& Kauranen, I. (2016). Open innovation in SMEs: A Systematic Literature Review. Journal of Strategy and Management, Vol. 9, No. 1, pp. 58-73 [In English]. https: / /doi.org/10.1108/JSMA-08-2014-0072.

10. Lehrer, C., Wieneke, A., vom Brocke, J., Jung, R. \& Seidel, S. (2018). How Big data Analytics Enables Service Innovation: Materiality, Affordance, and the Individualization of Service. Journal of Management Information Systems, Vol. 35, Issue 2, pp. 424-460 [In English]. https://doi.org/10.1080/07421222.2018.1451953.

11. Nilsson, N. \& Minssen, T. (2018). Unlocking the Full Potential of Open Innovation in the Life Sciences Through a Classification System. Drug Discovery Today, Vol. 23, Issue 4, pp. 771 775 [In English]. https://doi.org/10.1016/j.drudis.2018.01.002.

12. Platzek, B.P. \& Pretorius, L. (2020). Regional Cooperation in a Thriving Entrepreneurial Economy: A Holistic View on Innovation, Entrepreneurship and Economic Development. International Journal of Innovation and Technology Management, Vol. 17, No. 03, 2050014 [In English]. https: / /doi.org/10.1142/S0219877020500145.

13. Zulkepli, Z.H., Hasnan, N. \& Mohtar, S. (2015). Communication and Service Innovation in Small and Medium Enterprises (SMEs). Procedia - Social and Behavioral Sciences, Vol. 211, pp. 437-441 [In English]. https://doi.org/10.1016/ j.sbspro.2015.11.057.

14. Wynarczyk, P., Piperopoulos, P. \& McAdam, M. (2013). Open Innovation in Small and Medium-Sized Enterprises: An Overview. International Small Business Journal, Vol. 31, Issue 3, pp. 240-255 [In English]. https://doi.org/10.1177/0266242612472214.

15. Dahlander, L. \& Gann, D.M. (2010). How Open is Innovation. Research Policy, Vol. 39, Issue 6, pp. 699-709 [In English]. https://doi.org/10.1016/j.respol.2010.01.013.

16. Grimaldi, D. (2020). Factors Affecting Big Data Analytics Based Innovation Processes. A Spanish Evidence. International Journal of Innovation and Technology Management, Vol. 17, No. 05, 2050036 [In English]. https://doi.org/10.1142/S0219877020500364.

17. Grönlund, J., Sjödin, D.R. \& Frishammar, J. (2010). Open Innovation and the Stage-Gate Process: A Revised Model for New Product Development. California Management Review, Vol. 52, Issue 3, pp. 106-131 [In English]. https: / /doi.org/10.1525/cmr.2010.52.3.106.

18. Hall, B.H., Lotti, F. \& Mairesse, J. Innovation and Productivity in SMEs: Empirical Evidence for Italy, Small Business Economics. 2009. Vol. 33, pp. 13-33 [In English]. https://doi.org/10.1007/s11187-009-9184-8.

19. Muralidharan, E. \& Pathak, S. (2020). Contextualizing Technology Adoption and Self-Expression for Technology Entrepreneurial Innovation. International Journal of Innovation and Technology Management, Vol. 17, No. 04, 2050026 [In English]. https: / /doi.org/10.1142/S0219877020500261.

20. Spithoven, A., Clarysse, B. \& Knockaert, M. (2011). Building Absorptive Capacity to Organise Inbound Open Innovation in Traditional Industries. Technovation, Vol. 31, Issue 1, pp. 10-21 [In English]. https://doi.org/10.1016/j.technovation.2010.10.003.

21. Fadelelmoula, A.A. (2020). Factors Influencing the Realization of Competitive Advantage in the Private Portals Context. International Journal of Innovation and Technology Management, Vol. 17, No. 04, 2050028 [In English]. https: / /doi.org/10.1142/S0219877020500285.

22. Sağ, S., Sezen, B. \& Güzel, M. (2016). Factors that Motivate or Prevent Adoption of Open Innovation by SMEs in Developing Countries and Policy Suggestions. Procedia - Social and Behavioral Sciences, Vol. 235, pp. 756-763 [In English]. https://doi.org/10.1016/j.sbspro.2016.11.077. 
Чан Сі Цо. Аналіз впливу факторів інноваційної активності підприємств агропромислового комплексу на стійкість їх економічного розвитку

Мета статmi - розробити новий методичний підхід до аналізу інноваційної активності підприємств АПК з метою забезпечення їх сталого економічного розвитку з урахуванням факторів економічного зростання.

Методика дослідження. Використано наукові положення з планування інноваційної діяльності й аналізу інноваційних процесів (обгрунтовано сутність та зміст інноваційної активності підприємств), моделювання й організації інноваційної діяльності, прогнозування їі результатів в економічних системах (проаналізовано сучасні тенденції розвитку методів аналізу й оцінки інноваційної активності підприємств у системі оцінки ефективності інноваційної діяльності), а також загальнонаукові методи пізнання: системний (сформульовано проблеми оцінки інноваційної активності підприємств з позицій забезпечення їх сталого розвитку і визначення потенційних шляхів вирішення); комплексний (виконано аналіз параметрів інноваційної активності вітчизняних підприємств); абстрактно-логічний (проаналізовано вплив факторів зовнішнього середовища на інноваційну активність підприємства); функціональний і структурно-рівневий методи досліджень (розглянуто взаємозв'язок внутрішніх факторів інноваційної активності підприємства); методи аналізу і синтезу (проаналізовано взаємозв'язок внутрішніх факторів інноваційної активності підприємства); еволюційний та історичний підходи (розглянуто взаємозв'язок факторів інноваційної активності підприємства з параметрами його сталого розвитку).

Результати дослідження. Теоретично обгрунтовано методологічні основи інноваційної активності підприємств АПК як ступеня інтенсивності їх дій щодо створення та освоєння (практичної реалізації) нововведень в умовах швидкозмінних зовнішніх умов і жорсткої ринкової конкуренції. Попри високу ціну помилок в інноваційному розвитку підприємств АПК, аналіз інноваційної активності підприємства є важливим інструментом забезпечення їх сталого економічного розвитку.

Елементи наукової новизни. Наведено теоретичне обгрунтування та експериментальне підтвердження нового методичного підходу до аналізу інноваційної активності підприємств АПК з метою забезпечення їх сталого економічного розвитку, що дозволяє визначити інструменти інтенсифікації їх діяльності за рахунок нарощування і продуктивного використання інтелектуального потенціалу. Уточнено поняття «інноваційна активність підприємств» $і$ показано, що це одна з основоположних характеристик їх інноваційної діяльності. Удосконалено склад параметрів інноваційної активності підприємств та визначено сукупність факторів, що стимулюють і стримують інноваційну активність підприємств АПК. На основі проведених аналітичних досліджень виявлено взаємозв'язок і потужність взаємного впливу факторів інноваційної активності підприємств, а також зв'язок цих чинників з параметрами сталого економічного розвитку.

Практична значущість. Полягає в можливості використання наведених положень $і$ висновків під час аналізу взаємозв'язку внутрішніх факторів інноваційної активності підприємства, а також при аналізі зв'язку факторів інноваційної активності підприємств АПК з оцінкою стійкості їх ринкового розвитку. Запропонований комплекс методичних рекомендацій дозволяє здійснювати оцінку інноваційної активності підприємства в інтересах його сталого економічного розвитку. Табл.: 2. Бібліогр.: 22.

Ключові слова: аналіз; агропромисловий комплекс; інноваційна діяльність; економіка; підприємство; розвиток; стійкість; фактори.

Чан Сі Цо - аспірант кафедри економіки підприємства, Київський національний університет імені Тараса Шевченка (01033, м. Київ, вул. Володимирська, 60)

E-mail: changshichao8888@126.com

ORCID iD https://orcid.org/0000-0003-2945-5220

Чан Си Цо. Анализ влияния факторов инновационной активности предприятий агропромышленного комплекса на устойчивость их экономического развития

Цель статьи - разработать новый методический подход к анализу инновационной активности предприятий АПК с целью обеспечения их устойчивого экономического развития с учётом факторов экономического роста.

Методика исследования. Использованы научные положения по планированию инновационной деятельности и анализа инновационных процессов (обоснованы сущность и содержание инновационной активности предприятий), моделирования и организации инновационной деятельности, прогнозирование ее результатов в экономических системах (проанализированы современные тенденции развития методов анализа и оценки инновационной активности предприятий в системе оценки эффективности инновационной деятельности), а также общенаучные методы познания: системный (сформулированы проблемы оценки инновационной активности предприятий с позиций обеспечения их устойчивого развития и определения потенциальных путей решения); комплексный (выполнен анализ параметров инновационной активности отечественных предприятий); абстрактно-логический (проанализировано влияние факторов внешней среды на инновационную активность предприятия); функциональный и структурно-уровневый методы исследований (рассмотрена взаимосвязь внутренних факторов инновационной активности предприятия); методы анализа и синтеза (проанализирована взаимосвязь внутренних факторов инновационной активности предприятия); эволюционный и исторический подходы (рассмотрена взаимосвязь факторов инновационной активности предприятия с параметрами его устойчивого развития).

Результаты исследования. Теоретически обосновано методологические основы инновационной активности предприятий АПК как степени интенсивности их действий по созданию и освоению (практической реализации) нововведений в условиях быстро меняющихся внешних условий и жесткой рыночной конкуренции. Несмотря на высокую цену ошибок в инновационном развитии предприятий АПК, анализ инновационной активности предприятия является важным инструментом обеспечения их устойчивого экономического развития.

Элементы научной новизны. Приведены теоретические обоснования и экспериментальное подтверждение нового методического подхода к анализу инновационной активности предприятий АПК с целью обеспечения их устойчивого экономического развития, что позволяет определить инструменты интенсификации их деятельности за счет наращивания и продуктивного использования интеллектуального потенциала. Уточнено понятие «инновационная активность предприятий» и показано, что это одна из основных характеристик их инновационной деятельности. Усовершенствован состав параметров инновационной активности предприятий и определена совокупность факторов, что стимулируют и сдерживают инновационную активность предприятий АПК. На основе проведенных аналитических исследований выявлена взаимосвязь и мощность взаимного влияния факторов инновационной активности предприятий, а также связь этих факторов с параметрами устойчивого экономического развития.

Практическая значимость. Заключается в возможности использования приведенных положений и выводов во время анализа взаимосвязи внутренних факторов инновационной активности предприятия, а также при анализе связи факторов инновационной активности предприятий АПК с оценкой устойчивости их рыночного развития. Предложенный 
комплекс методических рекомендаций позволяет осуществлять оценку инновационной активности предприятия в интересах его устойчивого экономического развития. Табл.: 2. Библиогр.: 22.

Ключевые слова: анализ; агропромышленный комплекс; инновационная деятельность; экономика; предприятие; развитие; устойчивость; факторы.

Чан Си Цо - аспирант кафедры экономики предприятия, Киевский национальный университет имени Тараса Шевченко (01033, г. Киев, ул. Владимирская, 60)

E-mail: changshichao8888@126.com

ORCID iD https://orcid.org/0000-0003-2945-5220

The article has been received 09.11.2020

Revision: 16.11 .2020

Бібліографічний опис для цитування:

Chang Shichao. Analysis of the influence of factors of innovative activity of agro-industrial complex enterprises on the stability of their economic development. Економіка АПК. 2021. № 1. С. 84 - 94. https://doi.org/10.32317/2221-1055.202101084

Chang, Shichao (2021). Analysis of the influence of factors of innovative activity of agro-industrial complex enterprises on the stability of their economic development. Ekonomika APK, 1, pp. $84-94$ [In English] https://doi.org/10.32317/2221-1055.202101084

\title{
УДК 338
}

JEL Classification: Q18; Q13

DOI: https://doi.org/10.32317/2221-1055.202101094

В. В. РУСАНЮК, acnipaHm*

\section{Державне регулювання розвитку підприємництва в аграрному секторі}

\begin{abstract}
Mета статmi - розкрити сутність і основні напрями державного регулювання розвитку підприємництва в аграрному секторі в сучасних умовах.

Методика дослідження. Методологічною основою дослідження стала сукупність методів наукового пізнання системи та механізму державного регулювання розвитку підприємництва в аграрному секторі. Досягненню мети сприяли загальнонаукові методи: емпірічних досліджень (вимірювання, порівняння, спостереження); теоретичних досліджень (аналіз і синтез); а також локальні (специфічні): аналізу ситуації (розрахунково-конструктивний метод).

Результати дослідження. Встановлено, що державне регулювання розвитку підприємництва в аграрному секторі - цілісність реалізованих протекціоністських заходів, що гарантують фінансову, бюджетну, правову, економічну, інвестиційну безпеку конкурентоспроможного функціонування суб'єктів підприємництва в ринковому середовищі з метою оптимізації умов і наслідків підприємницької діяльності, формування гідного рівня продовольчої безпеки держави, адаптації товаровиробників до сучасних умов нестабільності та коронакризи. Обгрунтовано, що фінансові витрати на державну підтримку сільськогосподарських товаровиробників повинні становити не менше 1\% обсягу випуску сільськогосподарської продукції, за теперішніх 0,4\%. Виявлено відсутність реальної податкової підтримки сільськогосподарських товаровиробників. Встановлено, що реалізація пріоритетності державного регулювання малих суб'єктів підприємництва, фізичних осіб-підприємців і домогосподарств тільки сприятиме підвищенню інтегральної ефективності використання бюджетних коштів.

Елементи наукової новизни. Розкрито сутність та основні напрями державного регулювання розвитку підприємництва в аграрному секторі в сучасних умовах та запропоновано методичний підхід до обгрунтування основних напрямів модифікації державного регулювання, що сприяють вирішенню проблем функціонування підприємництва в аграрному секторі економіки. Акцентовано увагу на основні складові витрат за програмами державної підтримки розвитку підприємництва в аграрному секторі на 2021-2023 рр.

Практична значущість. Методичний підхід доцільно використовувати як базу в системі аналізу показників державного регулювання розвитку підприємничтва в аграрному секторі відповідно до даних статистичної звітності суб'єктів підприємництва і макропоказників соціально-економічного стану країни. Табл.: 1. Рис.: 1. Бібліогр.: 25.
\end{abstract}

(ㄱ В. В. Русанюк, 2021

* Науковий керівник - М. Й. Малік, доктор економічних наук, професор, академік НААН. 